season again a special watch was kept for any spretus which might be taken during the collecting hours, resulting, as we had supposed from observations in the field, in the taking of no specimens of spretus whatever. On careful examination of this material, however, we find what we believe to be one specimen of spretus, a female.
These notes are here recorded since the absence and recurrence of spretus is never without interest. Not present in this territory in 1897 , we find it in limited numbers in 1898 and this season out of all the material taken during four weeks collecting in Hamilton, Ford and Russell counties but one doubtful specimen among the captures.

\title{
THE GENUS KERMES IN NORTH AMERICA.
}

BY GEO. B. KING, LAWRENCE, MASS.

When I first thought of writing upon this genus it was my intention to take up the European species, but owing to the fact that I have not yet been able to consult some of the more important European literature treating upon the species found, and also that I wish to possess or at least see most of the species, I have abandoned it for the present, and taken up our North American forms. As there are not sufficient specific microscopical characters in the adult female to formulate a table of the species I have thought it best to put them into sections, based upon a superficial examination of the female scale.

I. Section of Kermes galliformis Riley. Globular forms, or nearly so, segmentation obscure; not gibbous. $K$. boyuei, $K$. pubescens, $K$. nigropunctatus, $K$. kingii, $K$. ceriferus, $K$. pettiti, $K$. austini, $K$. grandis, $K$. perryi, and $K$. galliformis var. cueroensis, n. var.

2. Section of Kermes gillettei Ckll.
Scales gibbous, segmentation distinct, $K$. concinnulus and $K$. cockerelli.

3. Section of Kermes nivalis King, Ckll. Scales shaped like a convex Lecanium, not globular or gibbous.

4. Section of Kermes andrei King. Scales very convex, elongated or pyriform in shape.

Prof. Cockerell finds Boitard, in I 828 , the earliest author to use Kermes as a true generic name. Of course Kermes (as he says) was used as a popular term for many years before Boitard's time, as will be seen when I treat of the European species. The total number of Kermes described is 26 and one variety, with one more yet to be named by Newstead, found in Africa. The name $K$. quercus was proposed for it, but this is preoccupied. Europe has I 2 and North America I5 species and one variety. The Kermesinae therefore contains 27 species and one variety, all of which belong to one genus, Kermes. The localities which have produced new species in North 
America are: New York, I ; Arizona, I ; Oklahoma, I ; Colorado, I ; Kansas, 2; California, 3; Massachusetts, 4; Mexico, I; and one variety from Texas. Although Kermes were known before the time of Moses, there were none described from America until June, I88I. A brief synopsis of the species follow in the order in which they were originally described.

I. Kermes galliformis Riley, I88I. A large, dark, dirty gray form, which turns to a nearly clear white color when exposed a season on the twigs. $q$ scale $6 \mathrm{~mm}$. long, 7 broad, 6 high, with black spots, and viewed with a hand lens the scale is seen to be covered with minute black specks. Newly hatched larva dirty gray. See tables. Originally described from Iron Mountain, Mo., and Silver City, New Mexico, the latter collected by Mr. H. H. Rusby, on 2uercus emoryi, also recorded from Colorado, Florida, Connecticut, South Carolina, and Massachusetts. A new locality is Las Vegas, New Mexico, March, 1900 (Cockerell and Porter).

Bibliography. - American Naturalist, vol. I5, I88I, p. 482. U. S. Agr. Rept. I880-8r, p. 337, U. S. Entom. Com. I89o, p. Ioo. Can. Ent. vol. 31, I899, p. I39.

Ia. Kermes galliformis, var. cueroensis. Cockerell, n. var. "Large, transverse diameter $8 \mathrm{~mm}$, convex, with no median constriction; brownish-white, obscurely marbled with very pale gray, with linear transverse brown bands, somewhat wavy, and thickened at intervals; surface minutely speckled with brown dots. On small branches of post oak (2uercus sp.), at Cuero, Texas, June 2, I898, collected by Prof. C. H. T. Townsend" (T. D. A. Cockerell, MS.).

After my MS. was sent to the printer Prof. Cockerell sent me some of the young larvae of the above variety, and I find them very different from any yet described, and belong to the galliformis group; the following is a description of them.

O larvae light yellow, elongate oval, 400 long, 200 broad. Antennae 6-jointed, 3, 6 and $I$ equal in length and longest, 2, 4 and 5 equal and short, nearly as broad as long. All the measurements are in micromillimeters, joints (I) 20 (2) 12 (3) 20 (4) I 2 (5) I 2 (6) 20. Formula (36r) (245), I, 4 and 5 have two short bristles. 6 seem to have about nine or ten, two of these at the apical and very long. Marginal spines point backward and slightly curved, not very stout, I2 long. Caudal tubercles long, each with a long bristle 140 long, and three stout spines 20 long. Legs normal with the coxa 20 long. Femur with trochanter, 64; tibia, 28; tarsus, 48; claw, I6. Coxa, 36 broad. Femur with trochanter, 28; tibia, 16 ; tarsus, 16. The tarsus diminishes in breadth rapidly near the claw. Digitules of tarsus and claw normal, with sinall knobs. Mentum and rostral loop tinged with yellow, all the other parts are colorless after boiling in K. H. O.

2. Kermes gillettei Ck11., I895. $\quad$ s sale $8 \mathrm{~mm}$. long, 7.5 broad, 7 high. Segmentation distinct, dorsum with round tuberosities, general coloring white and dark brown mottled, usually with a white dorsal band. Young larva pale purplish pink. Antennae 6 jointed, 3 and 6 equal and longest, 4 and 5 equal and shortest and about as long as broad, 2 a little longer than 4 and much shorter than 3,3 about as lorig as 4 plus 5 . Formula (36) 2 (45). Described from Manitou, Colorado, on Quercus undulata. Coll. by Prof. Gillette, Nov. 26, 1894, also found in New Mexico, in Santa Fé Canon (Cockerell), and at Beulah (Cockerell and Porter, March, I900).

Bibl. - The Entomologist, London, I895, p. Ior. Hemiptera of Colorada, I895, p. I26. Psyche, vol. 9, I900, p. 44.

3. Kermes boguei Ckll., 1897. ㅇ scale globular, $6 \frac{1}{2} \mathrm{~mm}$. long, $5 \frac{3}{4}$ broad, 5 high, smooth, not shining. Color dark, irregular 
blotching of scarlet, black and dull white; young larva reddish purple (after boiling). Antennae 6 jointed, 3 longest, 6 nearly as long as three, 2 broader than long, 5 shortest. Formula 36 (2 I) 45. Hab. about ro miles from Stillwater, Oklahoma, on 2uercus alba. Coll. by Prof. Bogue, Aug. 26, 1896.

Bibl. - Entomological News, vol. 8, 1897 , p. 94. Psyche, vol. 9, r 900, p. 44.

4. Kermes grandis Ckll., 1898 . O scale globular, ıo $\mathrm{mm}$. in diameter, surface dull, marbled with black gray and white. Hab. - Amecameca, Mexico, on 2uercus engelmanni. Coll. by Mr. Koebele, May 25, I 897 .

Bibl. -Ann. and Mag. Nat. Hist., ser. 7, vol. II., June, r898, p. 43I. Biol. Centr. Amer. Rhynch. Homop. vol. 2, Pt. 2, Dec., 1899, p. io. Psyche, vol. 9, 190o, p. 44.

5. Kermes fubescens Bogue, 1890. ㅇ scale globular, $3 \frac{1}{2} \mathrm{~mm}$. in diameter, 3 high. Color light brown, with suffused dark brown bands marking the obscure segments. Surface shining, minutely pubescent. Hab. - Manhattan, Kansas, on 2uercus macrocarpa and 2. prinoides. Coll. by Mr. Norton, Nov. I4, I 897 , also found at Lawrence, Andover, and Methuen, Mass., on 2uercus alba and 2. rubra. Coll. King, July, 1898 .

Bibl. - Can. Ent. vol. 30, I898, p. 172. Can. Ent., vol. 3r, r899, p. I39. Psyche, vol. 9 , r 900, p. 44 .

6. Kermes concinnulus Ckll. I898. q scale $4 \frac{1}{2} \mathrm{~mm}$. broad, $3 \frac{1}{2}$ high, very convex rounded in front, flattened behind. Color lively ochreous, surface shining, segmentation very distinct. Hab. - Manhattan, Kansas, on 2uercus macrocarpa. Coll. $\mathrm{Mr}$. Norton, Nov. I4, 1897 .

Bibl. - Can. Ent. vol. 30, I898, p. 172. Psyche, vol. 9, I9oo, p. 44.

7. Kermes cockerelli Ehrh. 1898. ㅇ scale $5 \mathrm{~mm}$. long, 4.5 broad and 4 high, deeply segmented. There is a broad median longitudinal grove where the segmentation is obsolete; on each side of this the segments are strongly gibbous. Color light brown.
Larva yellow. Antennae 6 jointed. Formula 36 (12) 45. Hab. - Mountain view, California on 2uercus lobata. Coll. Mr. Ehrhorn June, 1898.

Bibl. - Entomological News, vol. 9, 1898 , p. 185. Psyche, vol. 9, I900, p. 44.

8. Kermes nigropunctatus Ehrh. and Ckll. 1898. क scale globular $4.5 \mathrm{~mm}$. long, 5.5 broad, nearly 4 high, not very pale ochreous, speckled all over with black, specks very small. Segmentation obscure. Larva oval, pink. Antennae 6-jointed. Formula 36r (45) 2. Hab.- Los Angeles, California, on 2uercus sp. Coll. by Mr. Craw, June, I898. In Mexico; mouth of San Diego Canon, Sierra Madre, State of Chihuahua, on live oak, 2uercus sp. Coll. by Prof. Townsend, May 22, 1899. Originally described from California.

Bibl. - Entomological News, vol. 9, I898, p. I86. Biol. Centr. Amer. Rhynch. Homop. vol. 2, pt. 2, 1899, p. io. Psyche, vol. 9, r9oo, p. 45 .

9. Kermes nivalis King and Ck11. $\mathrm{I} 898$. o scale Lucanium-like in shape, $4 \frac{1}{2} \mathrm{~mm}$. long, $4 \frac{1}{2}$ broad and 3 high. Color dark sepiabrown, irregularly marbled with black and pale ochreous. The entire scale is covered with a thick coating of snow-white powder. Hab. - Lawrence, Mass., on 2uercus alba. Coll. by King, July 28, 1898 .

Bibl. - Ann and Mag. Nat. Hist. Ser. 7, vol. 2, Oct. 1898, p. 330. Can. Ent. vol. 31, I899, p. 139. Psyche, vol. 9, 1900, p. 44 .

Io. Kermes kingii Ckll. r898. क o scale globular, $5 \mathrm{~mm}$. long, $4 \frac{1}{3}$ broad, $3 \frac{1}{2}$ high. Color bright light ochreous, slightly marbled with a darker redder tint, with a pale mid dorsal line. Hab. - Lawrence, Mass., on 2uercus rubra. Coll. by King, July 28, 1898. Also found by Prof. Gillette a few years previous in Delaware, and then taken for $K^{*}$. galliformis.

Bibl. - Ann. and Mag. Nat. Hist. Ser. 7, vol. 2, 1889, p. 330. Can. Ent. vol. 31, 1899, p. I39. PSYCHE, vol. 9, I9Oo, p. 44. 
II. Kermes coriferus Ehrh. I899. $q$ scale globular 4 to $4 \frac{1}{2} \mathrm{~mm}$. in diameter. Color brown, shiny, dotted with black spots and coated with a dirty white wax. Larva reddish. Antennae 6 jointed, 3 and 6 about equal, $I$ and 2 equal, 4 and 5 equal. Formula (63) (12) (45). Hab. - Walnut Creek Canyon near Flagstaff, Arizona, on Quercus Sp.

Bibl. - Can. Ent. vol. 31, 1899, p. 5. Psyche, vol. 9, r9oo, p. 44.

12. Kermes pettiti Ehrh. 1899. $\$$ scale globular, $4 \mathrm{~mm}$. long, 4 broad, $3 \frac{1}{2}$ high. Color french yellow with black spots and obscure black specks (visible only with a hand lens, as in galliformis), with a prominent longitudinal constriction. The young larvae are yellow, and resemble structurally those of galliformis, whose larvae are dark gray. Pettiti scales do not lose their yellow color in the cabinet, as do galliformis; $K$. pettiti is very near to galliformis, but nevertheless it is a valid species. Prof. Cockerell informs me that the material was small and poor from which Mr. Ehrhorn described, and according to one of the type lot sent me, it seems as though there was another species mixed with his lot of a reddish-brown color, with darker brown spots. I find these in Massachusetts also with $K$. pettiti, and think this will prove to be a new species when its larva is found. Hab. - Ithaca, N. Y., on 2uercus $S \not p$. Coll. by Mr. Pettit, I898, at Lawrence, Mass., on 2uercus alba and 2. rubra, Sept. I897. Coll. by King, also found by Dr. Fletcher in Canada.

Bibl. - Can. Ent., vol. 31, 1899, p. 7 . Psyche, vol. 9, I900, p. 22. Psyche, vol. 9, I900, p. 45 .

13. Kermes austini Ehrh. 1899. $q$ scale globular, $4.5 \mathrm{~mm}$. broad, 4 long and 4 high, color light brown with several irregular white stripes running parallel with the segments. Young larva pink. Antennae 6 jointed, 3 longest then $6 ; 2$ and 5 subequal, I and 4 about equal. Formula 36 (25) (4I). Hab. - Guejito Mountains, eight miles east of Escondido, San Diego Co., California on 2uercus oblongifolia. Coll. by Mr. Austin, I 898 .

Bibl. - Can. Ent. vol. 31, r899, p. ro4 Psyche, vol. 9, I900, p. 44.

14. Kermes andrei King. 1900. \& scale very convex, $5 \mathrm{~mm}$. high and 5 in diameter at its base, surface shining. Color lightbrown with three and sometimes four dark brown bands. Hab. - Lawrence, Mass., on 2uercus alba and 2. rubra. Coll. King, Sept. 9, 1899.

Bibl. - Psyche, vol. 9, r9oo, p. 22. PsyCHE, vol. 9, I90o, p. 44.

15. Kermes perryi King n. sp. $q$ scale occurs on the twigs in clusters of 8 to I4. Shape, very globular, small, $3 \mathrm{~mm}$. in diameter. Superfically examined, its color appears to be dark gray, dull, not shining, very near the color of the bark upon the twig. Viewed with a hand lens the segmentation is nearly obsolete and indicated by fine black lines, upon a dark yellowish brown surface. Parallel with the segments are several depressed dots, which are darker than the surface. The entire surface of the scale is covered more or less with a dirty white wax; under a low power of the microscope this appears to be small white granular crystals. Boiled in K. O. H. it turns the liquid dark brown. Dermis by transmitted light colorless, with small round gland-orifices. Rostral loop long, and stout. Antennae short, stout, ro8 long. Apparently six jointed but the joints are indistinct, joint $I$ is 80 broad, 6 is 20 broad, 3 appears to be the longest, the 6 has several short hairs. $q$ larva (newly hatched) dark yellow, oval, broader in front than behind, not elongate as in some species, 4I2 long, 240 broad at middle pair of legs. Antennae 6 jointed, joint 3 longest, then 6 ; I and 5 next and equal 2 and 4 shortest and equal. Formula 36 (15) (24), all of the joints have hairs except $I$ and 2 more being upon 5 and 6 , three of these are very long. Rostral loop stout, reaching a little beyond last pair of legs. Legs normal. Coxa 24 
long. Femur with trochanter 76. Tibia $3^{2 .}$ Tarsus 52. Claw 16. Tarsal and claw digitules quite long, slender and knobbed. Caudal tubercles quite large, 40 long, 28 broad at the base, each bearing one long bristle 120 long, and three short stout spines r6 long. The marginal spines a little curved and point backwards, these are 12 long. The space between each being 2o. All the measurements are in micromillimeters. Hab. Lawrence, Mass., on scrub oak. 2uercus ilicifolia, July 28,1898 . It is very distinct from all other American Kermes, and the smallest yet found. Its nearest ally is evidently Kermes ceriferus Enrh. but is easily separated from that species, by its much smaller size of the $q$ scale. The young larva also differ very materially from $K$. ceriferus and cannot be confounded with $K$. nigropunctatus which is large and pale ochreous, with minute black spots and a median longitudinal depressed line. It is nothing like $K$. pettiti Ehrh. which is a very common species in Massachusetts. This species is named after Mr. A. F. Perry for his many kind favors shown me in my laboratory work.

The Larvae. All of our young larva of Kermes seem to be oval or elliptical in shape; and all very similar structurally, excepting $K$. pubescens, described below. They have well developed caudal tubercles, with one very long setae, and usually three stout spines, excepting in $K$. boguei, which has the long setae and only one spine, and $K$. gillettei, which has the long setae and two spines. The antennae are all six jointed, and very similar in detail, with the third joint longest, except in $K$. ceriferus and $K$. pubescens, where the sixth joint is a little the longest. For convenience, I give here the antennal formulars of those not included in the table below. $K$. gillettei (36) $2(45)$; $K$. boguei, 36(2 r) 45; $K$. cockerelli, $3^{6}$ (г 2) $45 ; K$. nigropunctatus, $36(45) 2$; $K$. ceriferus (63) (12) (45); and $K$. austini, $3^{6}(25)(4 \mathrm{r})$. The following tables of measurements are in micromillimeters.

Antennal Segments of the North Easthrn Species.

$$
\begin{array}{llllllll}
\text { Forms } & \text { I } & 2 & 3 & 4 & 5 & 6 & \text { Formula } \\
\text { Total } & \text { length }
\end{array}
$$

$\begin{array}{llllllllll}\text { Kermes galliformis } & 20 & 16 & 24 & 12 & 16 & 24 & 36 \mathrm{I}(25)_{4} & \text { I12 }\end{array}$

$\begin{array}{llllllllll}\text { “ pettiti } \quad 20 & 16 & 24 & 12 & 16 & 24 & 361(25) 4 & \text { II2 }\end{array}$

$\begin{array}{lllllllllll}\text { “ pubescens } & 16 & 16 & 20 & 12 & 16 & 24 & 63(125)_{4} & 104\end{array}$

“ " nivalis $\quad 16 \quad 2028 \quad 16 \quad 16 \quad 24 \quad 362(145) \quad$ 121

$\begin{array}{llllllllll}\text { “ } & \text { kingii } & 20 & 16 & 28 & 12 & 16 & 24 & 36 \mathrm{I}(25) 4 & \text { 116 }\end{array}$

$\begin{array}{lllllllllll}\text { " andrei } & 20 & 16 & 24 & 12 & 16 & 24 & (36) \times(25) 4 & 112\end{array}$

“ perryi $16 \quad 12 \quad 24 \quad 12 \quad 16 \quad 20 \quad 36(15)(24)$ 100

Front Legs of the Same Species. Length and BREADTh.

\begin{tabular}{ccccccc}
\multicolumn{2}{c}{ Forms } & Coxa & Femur with & \\
trochanter & Tibia & Tarsus & Claw \\
Kermes galliformis & $20-36$ & $80-24$ & $36-20$ & $52-16$ & 16 \\
" & pettiti & & $72-28$ & $32-20$ & $60-16$ & 20 \\
"6 & pubescens & $32-36$ & $72-24$ & $32-24$ & $40-16$ & 12 \\
" & nivalis & $24-36$ & $72-24$ & $26-20$ & $52-16$ & 16 \\
" & kingii & $20-36$ & $76-24$ & $36-20$ & $56-16$ & 16 \\
" & andrei & & $60-28$ & $28-20$ & $40-16$ & 16 \\
" & perryi & $24-40$ & $76-24$ & $32-20$ & $52-16$ & 16
\end{tabular}

Other Characters.

\begin{tabular}{|c|c|c|c|c|c|c|}
\hline Forms & Color & Length & Breadth & Tubercle setae & Tubercle spines & Marginal spines \\
\hline Kermes galliformis & Dark brown & 480 & 260 & 212 & 24 & 12 \\
\hline " pettiti & French yellow & 420 & 236 & 200 & 20 & 20 \\
\hline pubescens & Same & 420 & 192 & 132 & I2 & 8 \\
\hline nivalis & Light yellow & 360 & 200 & 76 & 20 & 12 \\
\hline kingii & Reddish brown & $3^{60}$ & $x 68$ & 180 & 24 & $x 6$ \\
\hline andrei & Dark yellow & 360 & 160 & 120 & 28 & 28 \\
\hline perryi & Same & 412 & 240 & 120 & $x 6$ & I 2 \\
\hline
\end{tabular}


Figures of Kermes pubescens and $K$. kingii are given to show the relative differences there are in the larva stages of the northeastern species at least, and so

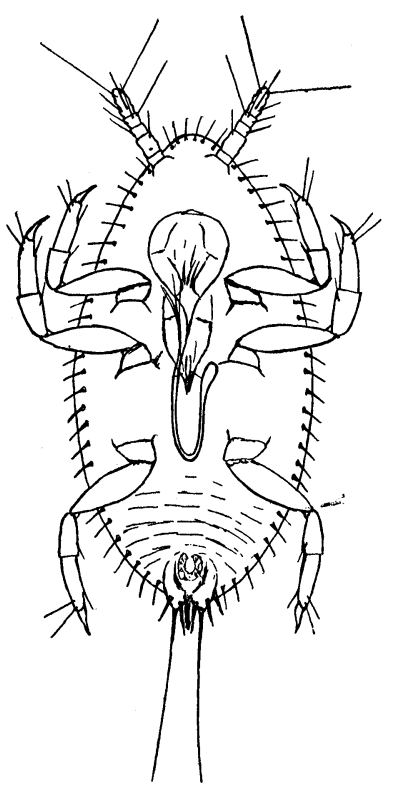

Young larva of $K$. kingii Ckll.

far as described they represent all yet found in North America. K. pubescens seems to differ from all the other forms and resemble much the genus Eriococcus, especially so in the shape of its spines; it looks much like Eriococcus eucalypti Mask.; pubescens has six rows, while eucalyptis body is thickly covered, pubescens caudal tubercles are very small, very different from all other species. The figure of $K$. kingii represents in a general way all the other forms of our Kermes larvae. In shape all are oval or slightly elongate oval, differing somewhat in color and in the measurements of their antennal segments, legs, etc. It is quite clear, as Mr. Pergande pointed out to Prof. Cockerell, that the

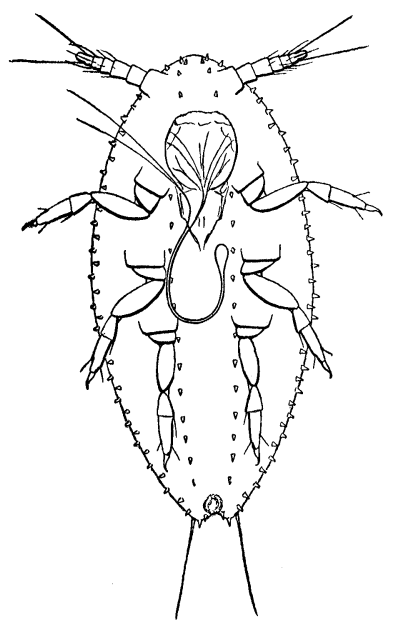

Young larva of $K$. pubescens Boguei.

Kermes in their larval stages are really allied to the genus Eriococcus, but in the adult stage they superficially resemble Lecanium. Something has been said by me and others to the effect that some of the species appear to be viviparous or perhaps parthenogenetic, but there may be some doubt about this. We have not found any of the winged $\delta$ forms. I have, however, met with several just lately in the larvae stage, not so large as the young $q$ larvae, but was not successful in getting mounts of any.

Parasites. Prof. Bogue has found $K$. pubescens to be attached by a Chalcid, also Prof. Ehrhorn finds $K$. cockerelli attacked by a chalcid sp. The depart- 
ment of Entomology at Washington have the following species bred from Kermes: Telenomus sp., Cosmocoma elegans, Blastobasis coccivorella, and also a Lepidopterous inquiline Euclemensia bassettella. Species bred by me and determined by Dr. Howard and Mr. Ashmead are from K. galliformis; Encyrtus sp., Cerchysius o, two species of Epiencyrtus and a genus unknown to Mr. Ashmead. Euclemensia bassettella, is quite frequently found. From $K$. pubescens, Microterys cincticornis has been bred. The size of Kermes in many of the species is so

\begin{tabular}{|c|c|c|}
\hline & & Forms \\
\hline * I & Kermes $q$ & galliformis Riley \\
\hline 2 & “6 & gillettei Ckll. \\
\hline 3 & “ & boguei Ckll. \\
\hline * 4 & “6 & pubescens Bogne \\
\hline 5 & "6 & concinnulus Ckll. \\
\hline 6 & " & cockerelli Ehrh. \\
\hline 7 & "6 & nigropunctatus Ehrh. \& Ckll. \\
\hline * 8 & " & nivalis King \& Ckll. \\
\hline * 9 & “ & kingii Ckll. \\
\hline Io & " & ceriferus Ehrh. \\
\hline *II & 66 & pettiti Ehrh. \\
\hline 12 & " & austini Ehrh. \\
\hline$*_{1} 3$ & 6 & andrei King \\
\hline * ${ }^{4} 4$ & 66 & perryi King \\
\hline I5 & " & galliformis var cueroensis Ckll. \\
\hline
\end{tabular}

variable that an approximate measurement only can be given, and all are found to infest different species of oaks in North America. The only species thus far doing any material damage to the trees are $K$. galliformis, $K$. pettiti and $K$. pubescens, which I really believe to be the most injurious species we have.

The following list gives all of our United States species of Kermes, together with the date of their discovery and publication. * indicates Massachusetts species.

\begin{tabular}{|c|c|}
\hline Published & Published in \\
\hline June, $\mathrm{x} 88 \mathrm{I}$ & American Naturalist, vol. I 5, I 88 I. P. ${ }_{482}$ \\
\hline April, 18 & Entomologist, 1895 , p. го \\
\hline April, 1897 & Entomological News, vol. 8, 1897. P. 94 \\
\hline $\begin{array}{c}\text { July, } \\
\text { “ } \\
\text { “ }\end{array}$ & 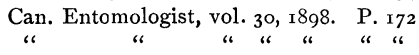 \\
\hline $\begin{array}{l}\text { Oct., } \\
\text { “ }\end{array}$ & $\begin{array}{c}\text { Entomological News, vol. } \\
\text { ، } \\
\text { ، }\end{array}$ \\
\hline “ & $\begin{array}{l}\text { Ann. \& Mag. of Nat. Hist., ser. } 7 \text {, vol. 2, } \\
\text { Oct., I } 898 . \text { P. } 33 \text { o. }\end{array}$ \\
\hline “ & $\begin{array}{l}\text { Ann. \& Mag. of Nat. Hist., ser. 7, vol. 2, } \\
\text { Oct., 1898. P. } 33^{\circ} \text {. }\end{array}$ \\
\hline$\underset{\text { Jan., }}{1899}$ & 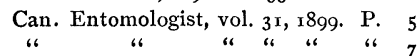 \\
\hline May, “ & " " " \\
\hline $\begin{array}{l}\text { Jan., } 1900 \\
\text { May, } 1900\end{array}$ & $\begin{array}{l}\text { Psyche, vol. 9, rgoo. P. } 22 \\
\text { Herein described } \\
\text { ، }\end{array}$ \\
\hline
\end{tabular}

\section{A. SMITH \& SONS, 146-148 WILLIAM ST., New York.}

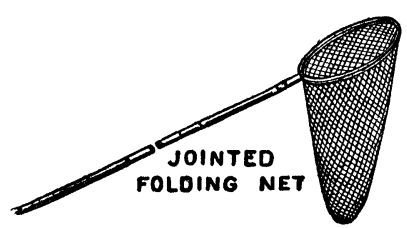
GOODS FOR EHTOMOLOGISTS,

Klaeger and Carlsbad Insect Pins, Setting

Boards, Folding Nets, Locality and Special Labels, Forceps, Sheet Cork, Eıc. Other articles are being added, Send for List.

THE BUTTERFLY BOOK. Imp. 8vo., Pp. $x x+382.48$ colored plates with over 1 , Ooo figures representing 525 species. 183 figures in text. Indispensable to collectors and students of entomology. 

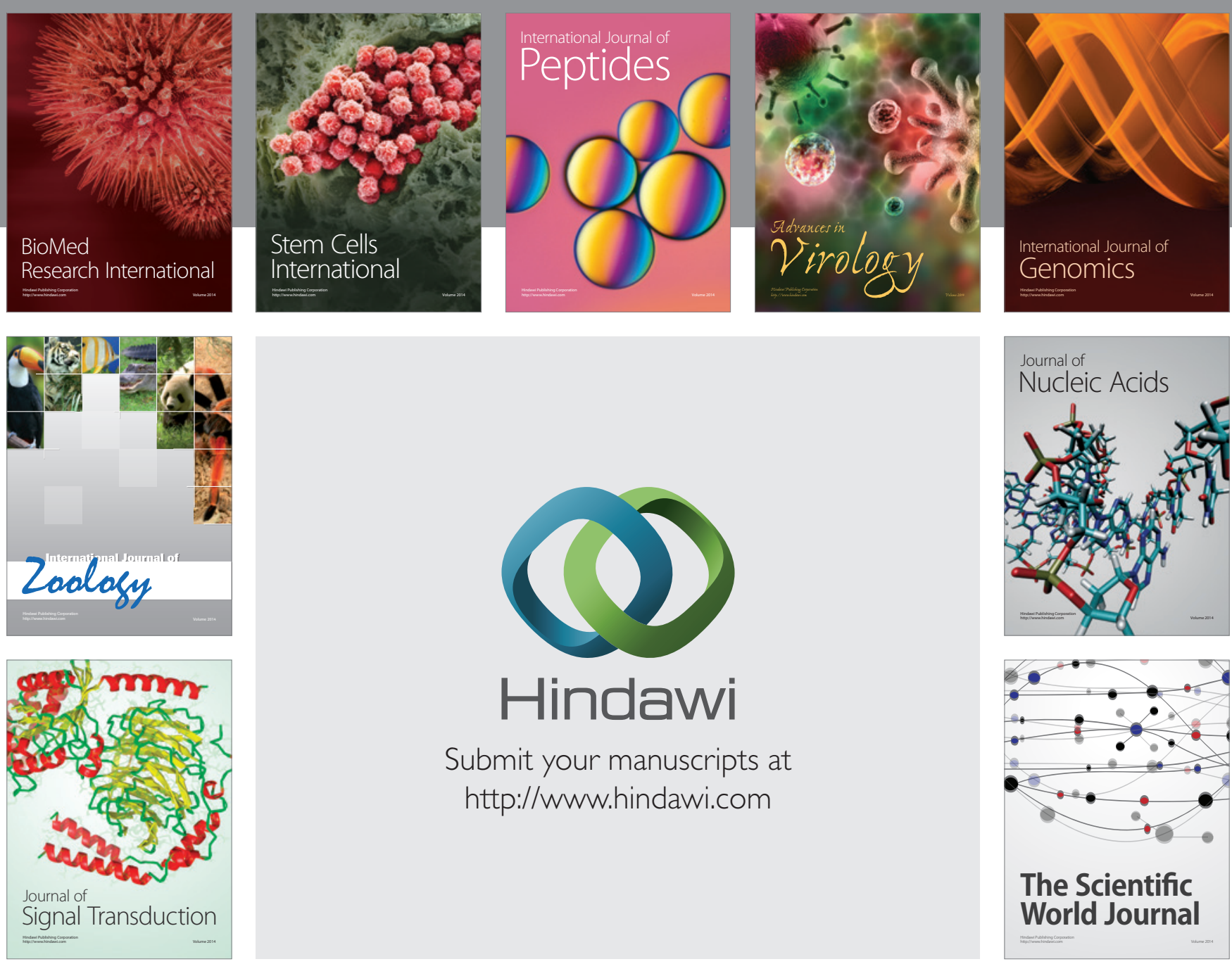

Submit your manuscripts at

http://www.hindawi.com
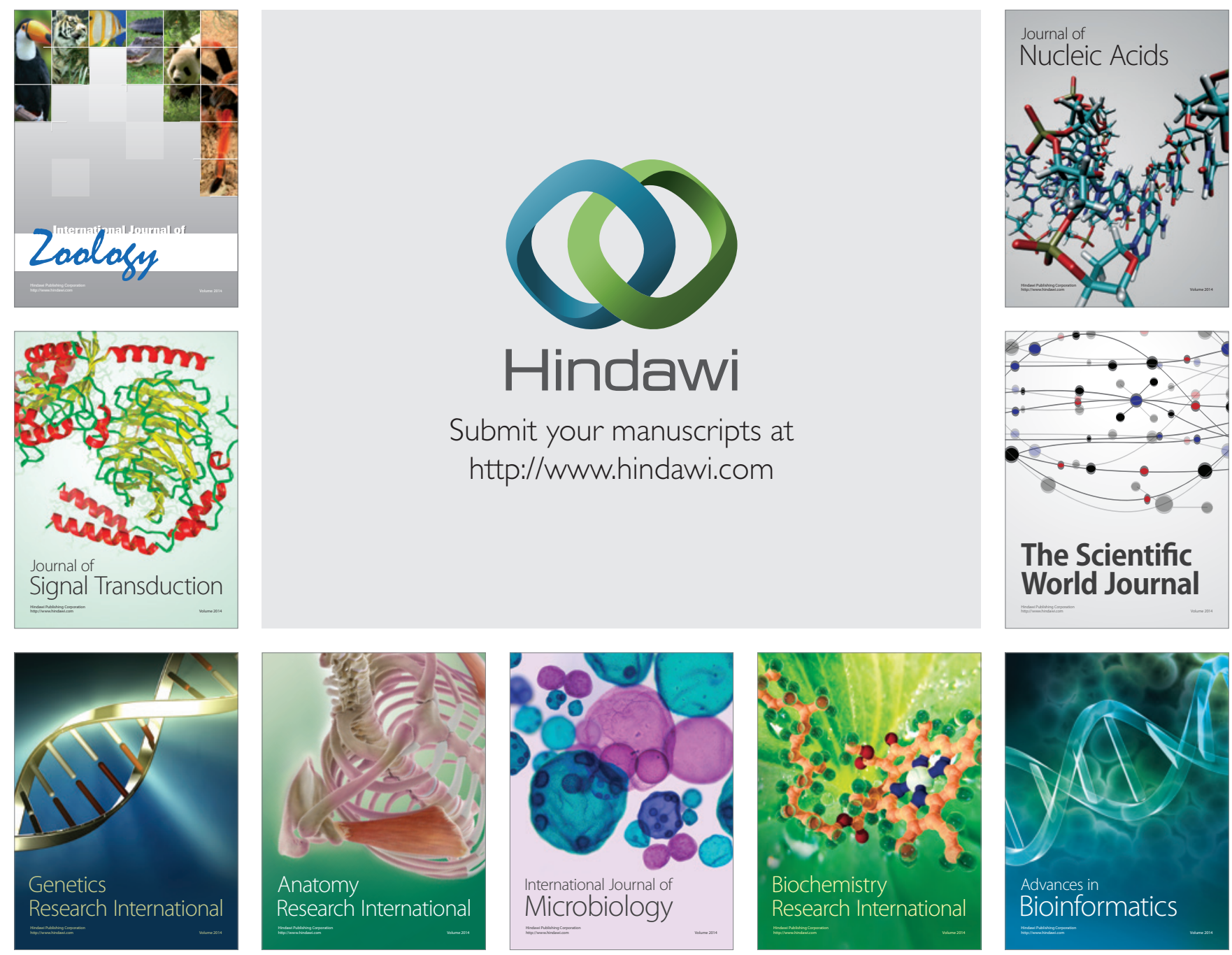

The Scientific World Journal
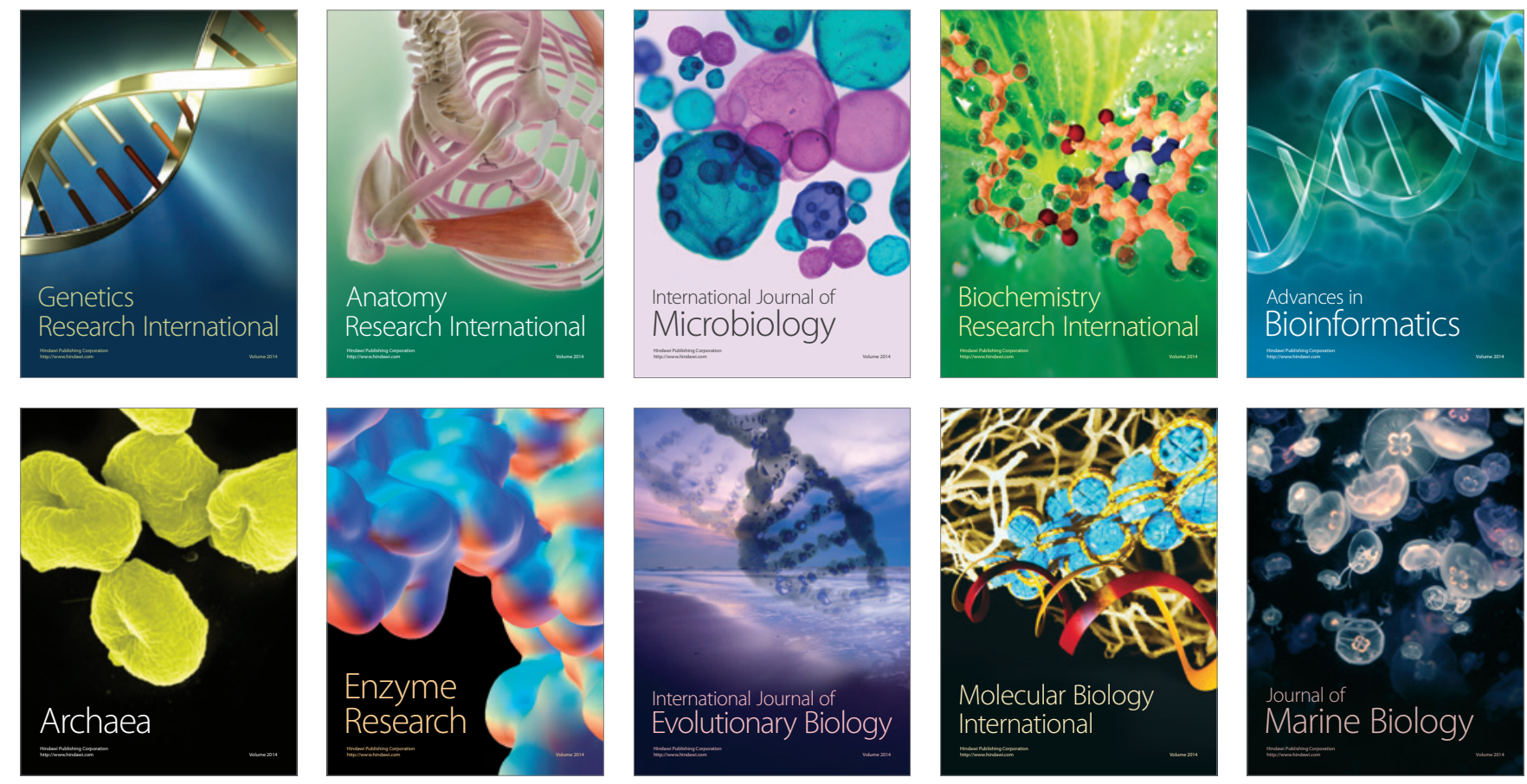